\title{
Identifikasi Cacat Prioritas pada Proses Shaving untuk Pengendalian Mutu
} Kualitas

\section{Identification of Priority Defects in the Shaving Process for Quality Control}

\author{
Mahmud Basuki*1 \\ ${ }^{1}$ Program Studi Teknik Industri, Fakultas Teknik, Universitas Tridinanti
}

ARTICLE INFO

Article history:

Diterima 22-11-2019

Diperbaiki 14-12-2019

Disetujui 27-12-2019

Kata Kunci:

Kulit, kecacatan, p-chart, diagram ishikawa
A B S T R A K

PT XYZ merupakan perusahaan yang bergerak di bidang penyamakan kulit sejak tahun 1966. Kulit yang digunakan oleh PT XYZ adalah kulit domba dan kulit kambing, dalam penggunaannya masing-masing mempunyai komposisi sebesar 50\%. Penelitian ini bertujuan untuk menganalisa kecacatan produk pada proses shaving (penyamakan) dengan menggunakan statistical quality control serta mengetahui faktorfaktor yang menjadi penyebab kecacatan produk menggunakan diagram Ishikawa. Hasil penelitian menunjukkan bahwa terdapat tiga macam kecacatan yaitu sobek, lorek, dan ketipisan. Dengan menggunakan diagram kontrol $\mathrm{p}$ (p-chart) terdapat data yang out of control sebanyak 5 buah data observasi dengan prioritas perbaikan yang harus dilakukan terlebih dahulu adalah kecacatan jenis sobek, ketipisan, dan terakhir lorek yang dianalisa penyebab produk defect tersebut menggunakan diagram Ishikawa.
Keywords:

Skin, disability, p-chart, ishikawa diagram

\section{A B S T R A C T}

PT XYZ is a company engaged in leather tanning since 1966. The skin used by PT XYZ is sheep skin and goat skin, each of which has a composition of $50 \%$. This study aims to analyze product defects in the process of shaving (tanning) by using statistical quality control and knowing the factors that cause product defects using Ishikwa diagrams. The results showed that there were three types of disabilities, namely tear, lorek, and thinness. By using the control chart $\mathrm{p}$ (p-chart) there are 5 out of control data observations with prioritization of repairs that must be done first is the type of tear, thinness, and finally lorek which analyzed the causes of product defects using Ishikawa diagram.

\section{Pendahuluan}

Setiap perusahaan akan berusaha memenuhi kebutuhan pelanggan secara maksimal untuk mencapai kepuasan pelanggan. Jika ingin tetap kompetitif dan berkembang, perusahaan harus memahami konsep kualitas layanan dan kepuasan pelanggan [1], dimana kepuasan adalah sesuatu yang dapat memenuhi keinginan, harapan, kebutuhan pelanggan serta tidak mendatangkan keluhan [2]. Salah satu kunci utama dalam proses perkembangan suatu perusahaan dilihat dari seberapa besar jumlah pelanggannya. Karena dengan peningkatan jumlah pelanggan, maka produksi juga akan bertambah dan keuntungan semakin meningkat. Sehingga diperlukan produk yang sesuai dan dapat memenuhi keinginan pelanggan. Di antaranya pelanggan mengharapkan produk yang berkualitas, bebas cacat, handal, memiliki daya tahan untuk beberapa waktu dan harga relatif terjangkau.
Fithri dan Chairunnisa menyatakan bahwa produk berkualitas yaitu produk yang memenuhi kriteria perusahaan yang telah ditetapkan dan sesuai dengan keinginan pelanggan [3].

Penelitian tentang pengendalian kualitas telah banyak dilakukan, diantaranya dilakukan pada proses produksi besi beton [4], pada proses pembuatan knalpot [5], pada proses produksi kertas [6], pada proses pembuatan tempe [7], pada proses pengendalian kualitas air [8], pada proses painting shop PT Toyota Motor Manufacturing Indonesia [9], dan pada Wing Structure Pesawat CN-235 [10]. Karena belum adanya penelitian tentang pengendalian kualitas pada proses penyamakan (shaving) kulit, maka peneliti akan melakukan penelitian pada proses penyamakan kulit (shaving process).

Salah satu perusahaan yang bergerak di bidang penyamakan kulit yaitu PT XYZ yang berdiri sejak tahun 1966. Untuk mendapatkan proses penyamakan yang sempurna, biasanya dibutuhkan perlakuan mekanik [11]. Pada 
umumnya ada 3 macam penyamakan yaitu penyamakan nabati (cara samak cepat), penyamakan mineral (penyamakan alumunium dan krom), dan penyamakan minyak [12].

PT XYZ memproses kulit mentah menjadi bentuk kulit jadi (finish leather). Dari kulit jadi tersebut dipasarkan kembali, bisa untuk dijadikan jaket, sepatu, tas, sarung tangan golf, dan lain sebagainya. Kulit domba dan kulit kambing menjadi bahan baku utama dalam penyamakan kulit. Proporsi bahan baku yang digunakan yaitu $50 \%$ kulit domba dan $50 \%$ kulit kambing. Namun secara kualitas, kulit domba lebih unggul dibandingkan dengan kulit kambing, hal ini diungkapkan oleh salah satu karyawan yang berada di lokasi produksi. Penggunaan kulit domba dan kulit kambing dilakukan karena bahan baku kulit di Indonesia tidak akan mencukupi jika hanya menggunakan kulit domba. Meski telah menggunakan kulit kambing juga, PT XYZ juga masih impor bahan baku kulit dari luar negeri untuk memenuhi kebutuhan produksinya. Berdasarkan data Statistik Indonesia Tahun 2018 populasi kambing lebih tinggi dibandingkan dengan populasi domba. Populasi kambing di Indonesia tercatat sebanyak 18.410.400 ekor, sedangkan populasi domba sebanyak 16.462.300 ekor. Populasi kambing terbanyak berada di Provinsi Jawa Tengah sebesar 22,45 \% (4.134.000 ekor), sedangkan populasi domba terbanyak berada di Provinsi Jawa Barat sebesar 65,09 \% (10.714.700 ekor) [13].

Dari pemaparan di atas, peneliti tertarik untuk melakukan penelitian pada proses shaving (penyamakan) untuk mengetahui proses yang terjadi apakah masih perlu pengendalian kualitas dalam proses penyamakan kulit, dengan adanya pengendalian kualitas diharapkan produk penyamakan kulit dari PT XYZ minim kecacatan. Apabila banyak produk yang cacat, maka produk bisa ditolak pasar, pelanggan bisa beralih ke yang lain. Menurut Basuki apabila pasar atau pelanggan menolak produk hasil produksi, maka akan terjadi pula penghambatan pada produksi, proses produksi tidak sesuai target, bahkan produksi akan terhenti [14]. Oleh karena itu, perlu dicarikan solusi perbaikannya jika masih terdapat produk defect serta mengetahui faktor-faktor yang menyebabkan produk defect tersebut. Dimana, defect adalah suatu masalah yang harus dikurangi [15].

Kualitas menurut American Society for Quality adalah totalitas fitur dan karakteristik produk maupun jasa yang dapat memberikan kepuasan terhadap kebutuhan pelanggan baik yang tampak maupun yang samar. Pengertian kualitas menurut beberapa ahli antara lain adalah: Juran (1962) mendefinisikan kualitas sebagai kesesuaian dengan tujuan atau manfaatnya. Crosby (1979) mendefinisikan kualitas sebagai kesesuaian dengan kebutuhan yang meliputi availability, delivery, realibility, maintainability, dan cost effectiveness. Deming (1982) mendefinisikan kualitas harus bertujuan memenuhi kebutuhan pelanggan sekarang dan di masa mendatang. Sedangkan, Feigenbaum (1991) mendefinisikan kualitas sebagai keseluruhan karakteristik produk dan jasa yang meliputi marketing, engineering, manufacture, dan maintenance, dimana produk dan jasa tersebut dalam pemakaiannya akan sesuai dengan kebutuhan dan harapan pelanggan.

Berdasarkan perspektif kualitas, David Garvin telah menguraikan kualitas ke dalam delapan dimensi yang dapat digunakan sebagai dasar perencanaan strategis terutama bagi perusahaan manufaktur yang menghasilkan barang. Kedelapan dimensi tersebut adalah sebagai berikut.

1. Performance (kinerja), yaitu kesesuaian produk dengan fungsi utama produk itu sendiri atau karakteristik operasi dari suatu produk.

2. Feature, yaitu ciri khas produk yang membedakan dari produk lain yang merupakan karakteristik pelengkap dan mampu menimbulkan kesan yang baik bagi pelanggan.

3. Reliability, yaitu kepercayaan pelanggan terhadap produk karena kehandalanya atau karena kemungkinan kerusakan yang rendah.

4. Conformance, yaitu kesesuaian produk dengan syarat atau ukuran tertentu sejauh mana karakteristik desain dan operasi memenuhi standar-standar yang telah ditetapkan.

5. Durability, yaitu tingkat ketahanan/awet produk atau lama umur produk.

6. Serviceability, yaitu kemudahan produk itu bila akan diperbaiki atau kemudian memperoleh komponen produk tersebut.

7. Aesthetic, yaitu keindahan atau daya tarik produk tersebut.

8. Perception, yaitu fanatisme pelanggan akan merek suatu produk tertentu karena citra atau reputasi produk itu sendiri.

Diagram Ishikawa (diagram tulang ikan) pertama kali ditemukan oleh Ishikawa pada tahun 1968 yang menunjukkan penyebab dari sebuah even yang spesifik. Diagram Ishikawa merupakan alat paling efektif untuk mengetahui penyebab suatu permasalahan yang dapat mempengaruhi kualitas proses [16]. Diagram tulang ikan berfungsi sebagai pencari sebab permasalahan sebagai tulang dengan masalah sebagai kepalanya. Pada umumnya faktor penyebab permasalahan dikelompokkan ke dalam 5 faktor utama berupa $5 \mathrm{M}+1 \mathrm{E}$ yaitu material, man, methode, machine, measurement dan environment [17].

\section{Metode Penelitian}

Dalam penelitian ini, metode yang digunakan dalam pengumpulan data adalah sebagai berikut:

\subsection{Observasi (pengamatan langsung)}

Pengamatan secara langsung ke perusahaan untuk mendapatkan data-data mengenai segala hal yang berkaitan dengan masalah yang diteliti dan sesuai dengan kebutuhan, yaitu mengindentifikasi cacat prioritas pada proses shaving untuk pengendalian mutu kualitas di PT XYZ.

\subsection{Wawancara}

Merupakan suatu metode dengan cara mengajukan sejumlah pertanyaan secara langsung kepada pihak yang berkompeten di perusahaan untuk mendapatkan data yang diperlukan dalam penelitian.

\subsection{Studi Pustaka}

Studi pustaka merupakan penunjang yang dapat mendukung dalam pengumpulan data dan membahas obyek penelitian. Studi pustaka dalam hal ini dilakukan untuk mempelajari tema penelitian dengan literatur yang terkait. 

berikut:

Langkah-langkah dalam penelitian ini adalah sebagai

\subsubsection{Menghitung proporsi kecacatan dengan rumus:}

$$
P=\frac{x}{n}
$$

dimana:

$\mathrm{p}=$ Proporsi kesalahan dalam setiap sampel

$\mathrm{x}=$ Banyaknya produk yang salah dalam setiap sampel

$\mathrm{n}=$ Banyaknya sampel yang diambil dalam observasi

2.3.2 Menghitung garis pusat (GP) atau center line dengan rumus:

$$
G P=\bar{p}=\frac{\sum_{i=1}^{g} p i}{g}=\frac{\sum_{i=1}^{g} x i}{\sum \text { rampel }}
$$

dimana:

$\bar{p}=$ Garis pusat peta pengendali proporsi kesalahan pi $=$ Proporsi kesalahan setiap sampel atau sub kelompok dalam setiap observasi

$\mathrm{xi}=$ Banyaknya kesalahan setiap sampel pada setiap kali observasi

$\mathrm{g}$ = Banyaknya observasi yang dilakukan

2.3.3 Menghitung Batas Pengendali Atas (BPA) dan Batas Pengendali Bawah (BPB) dengan rumus:

$$
\begin{aligned}
& \text { BPA } \mathrm{p}=\bar{p}+3 \sqrt{\frac{p(1-\bar{p})}{n i}} \\
& \text { BPB } \mathrm{p}=\bar{p}-3 \sqrt{\frac{p(1-\bar{p})}{n i}}
\end{aligned}
$$

dimana:

ni $=$ Banyaknya sampel yang diambil pada setiap kali observasi yang selalu bervariasi

\subsubsection{Menggambarkan peta $P$ menggunakan batas kontrol dan sebaran data $p$}

Menentukan kecacatan rangking tertinggi dari data out of control apabila terdapat data yang out of control, guna menemukan permasalahan yang paling penting untuk dapat diselesaikan terlebih dahulu (rangking tertinggi) sampai dengan masalah yang tidak harus segera diselesaikan (rangking terendah).

\section{Hasil dan Pembahasan}

Pengamatan dilakukan sebanyak 30 kali selama 30 hari kerja pada proses shaving untuk mengetahui jumlah produk yang tidak diharapkan (defect). Berikut adalah hasil pengamatannya:

\begin{tabular}{|c|c|c|c|c|c|}
\hline \multirow{2}{*}{ Observasi } & \multirow{2}{*}{$\begin{array}{c}\text { Jumlah } \\
\text { Lembar/ } \\
\text { hari }\end{array}$} & \multicolumn{3}{|c|}{ Data Cacat } & \multirow{2}{*}{$\begin{array}{l}\text { Total } \\
\text { Cacat }\end{array}$} \\
\hline & & Sobek & Lorek & Ketipisan & \\
\hline 7 & 128 & 0 & 0 & 0 & 0 \\
\hline 8 & 336 & 0 & 0 & 0 & 0 \\
\hline 9 & 570 & 0 & 0 & 0 & 0 \\
\hline 10 & 297 & 5 & 7 & 0 & 12 \\
\hline 11 & 659 & 0 & 11 & 0 & 11 \\
\hline 12 & 437 & 6 & 0 & 0 & 6 \\
\hline 13 & 696 & 0 & 0 & 0 & 0 \\
\hline 14 & 501 & 0 & 0 & 0 & 0 \\
\hline 15 & 339 & 0 & 0 & 0 & 0 \\
\hline 16 & 527 & 0 & 0 & 0 & 0 \\
\hline 17 & 681 & 25 & 0 & 0 & 25 \\
\hline 18 & 226 & 0 & 0 & 0 & 0 \\
\hline 19 & 428 & 2 & 0 & 0 & 2 \\
\hline 20 & 468 & 0 & 0 & 0 & 0 \\
\hline 21 & 200 & 0 & 0 & 0 & 0 \\
\hline 22 & 279 & 0 & 0 & 0 & 0 \\
\hline 23 & 332 & 0 & 0 & 0 & 0 \\
\hline 24 & 490 & 0 & 11 & 0 & 11 \\
\hline 25 & 93 & 0 & 0 & 0 & 0 \\
\hline 26 & 360 & 0 & 0 & 0 & 0 \\
\hline 27 & 297 & 4 & 7 & 11 & 22 \\
\hline 28 & 256 & 0 & 0 & 0 & 0 \\
\hline 29 & 278 & 0 & 4 & 0 & 4 \\
\hline 30 & 600 & 0 & 0 & 0 & 0 \\
\hline
\end{tabular}

Tabel 1.

Data Hasil Pengamatan

\begin{tabular}{|r|c|r|r|r|r|}
\hline \multirow{2}{*}{ Observasi } & \multirow{2}{*}{$\begin{array}{c}\text { Jumlah } \\
\text { Lembar/ } \\
\text { hari }\end{array}$} & \multicolumn{3}{|c|}{ Data Cacat } & \multirow{2}{*}{$\begin{array}{c}\text { Total } \\
\text { Cacat }\end{array}$} \\
\cline { 3 - 6 } & 250 & 1 & 0 & 10 & 11 \\
\hline 1 & Sobek & Lorek & Ketipisan & 10 \\
\hline 2 & 250 & 0 & 0 & 10 & 10 \\
\hline 3 & 548 & 5 & 0 & 0 & 5 \\
\hline 4 & 100 & 1 & 0 & 0 & 1 \\
\hline 5 & 737 & 0 & 0 & 0 & 0 \\
\hline 6 & 328 & 0 & 0 & 0 & 0 \\
\hline
\end{tabular}

Langkah selanjutnya yaitu menghitung proporsi cacat, Batas Pengendali Atas (BPA) dan Batas Pengendali Bawah (BPB).

3.1 Menghitung proporsi kecacatan dengan rumus:

$P=\frac{x}{n} \quad \rightarrow P_{1}=\frac{11}{250}=0.044$

3.2 Menghitung garis pusat (GP) atau center line dengan rumus:

$G P=\bar{p}=\frac{\sum_{i=1}^{g} P i}{g}=\frac{\sum_{i=1}^{g} X i}{\sum \text { sampel }}$
$G P=\frac{120}{11691}=0.01$

\subsection{Menghitung BPA dan BPB}

Observasi ke-1 dengan ukuran sampel 250, diperoleh Batas Pengendali Atas (BPA) dan Batas Pengendali Bawah (BPB) sebagai berikut:

$B P A=0.01+3 \sqrt{\frac{0.01(1-0.01)}{250}}=0.029$
$B P B=0.012375-3 \sqrt{\frac{0.01(1-0.01)}{250}}=-0.009$

Hasil selengkapnya terangkum pada tabel di bawah ini: 
Tabel 2.

Data Proporsi Kecacatan

\begin{tabular}{|c|c|c|r|r|r|}
\hline No & $\begin{array}{c}\text { Jumlah } \\
\text { Lembar/ } \\
\text { Hari }\end{array}$ & $\begin{array}{r}\text { Banyak } \\
\text { Produk } \\
\text { Cacat }\end{array}$ & $\begin{array}{c}\text { Proporsi } \\
\text { Cacat }\end{array}$ & BPA & BPB \\
\hline 1 & 250 & 11 & 0.044 & 0.029 & -0.009 \\
\hline 2 & 250 & 10 & 0.040 & 0.029 & -0.009 \\
\hline 3 & 548 & 5 & 0.009 & 0.023 & -0.003 \\
\hline 4 & 100 & 1 & 0.010 & 0.041 & -0.020 \\
\hline 5 & 737 & 0 & 0.000 & 0.021 & -0.001 \\
\hline 6 & 328 & 0 & 0.000 & 0.027 & -0.006 \\
\hline 7 & 128 & 0 & 0.000 & 0.037 & -0.016 \\
\hline 8 & 336 & 0 & 0.000 & 0.027 & -0.006 \\
\hline 9 & 570 & 0 & 0.000 & 0.023 & -0.002 \\
\hline 10 & 297 & 12 & 0.040 & 0.028 & -0.007 \\
\hline 11 & 659 & 11 & 0.017 & 0.022 & -0.002 \\
\hline 12 & 437 & 6 & 0.014 & 0.025 & -0.004 \\
\hline 13 & 696 & 0 & 0.000 & 0.022 & -0.001 \\
\hline 14 & 501 & 0 & 0.000 & 0.024 & -0.003 \\
\hline 15 & 339 & 0 & 0.000 & 0.027 & -0.006 \\
\hline 16 & 527 & 0 & 0.000 & 0.023 & -0.003 \\
\hline
\end{tabular}

\begin{tabular}{|c|c|c|c|c|c|}
\hline No & $\begin{array}{c}\text { Lumlah } \\
\text { Hari }\end{array}$ & $\begin{array}{c}\text { Banyak } \\
\text { Cacat }\end{array}$ & Proporsi & BPA & BPB \\
\hline 17 & 681 & 25 & 0.037 & 0.022 & -0.001 \\
\hline 18 & 226 & 0 & 0.000 & 0.030 & -0.010 \\
\hline 19 & 428 & 2 & 0.005 & 0.025 & -0.004 \\
\hline 20 & 468 & 0 & 0.000 & 0.024 & -0.004 \\
\hline 21 & 200 & 0 & 0.000 & 0.032 & -0.011 \\
\hline 22 & 279 & 0 & 0.000 & 0.028 & -0.008 \\
\hline 23 & 332 & 0 & 0.000 & 0.027 & -0.006 \\
\hline 24 & 490 & 11 & 0.022 & 0.024 & -0.003 \\
\hline 25 & 93 & 0 & 0.000 & 0.042 & -0.021 \\
\hline 26 & 360 & 0 & 0.000 & 0.026 & -0.006 \\
\hline 27 & 297 & 22 & 0.074 & 0.028 & -0.007 \\
\hline 28 & 256 & 0 & 0.000 & 0.029 & -0.009 \\
\hline 29 & 278 & 4 & 0.014 & 0.028 & -0.008 \\
\hline 30 & 600 & 0 & 0.000 & 0.023 & -0.002 \\
\hline & 11691 & 120 & & & \\
\hline
\end{tabular}

3.4 Gambar peta P menggunakan batas kontrol dan sebaran data $p$

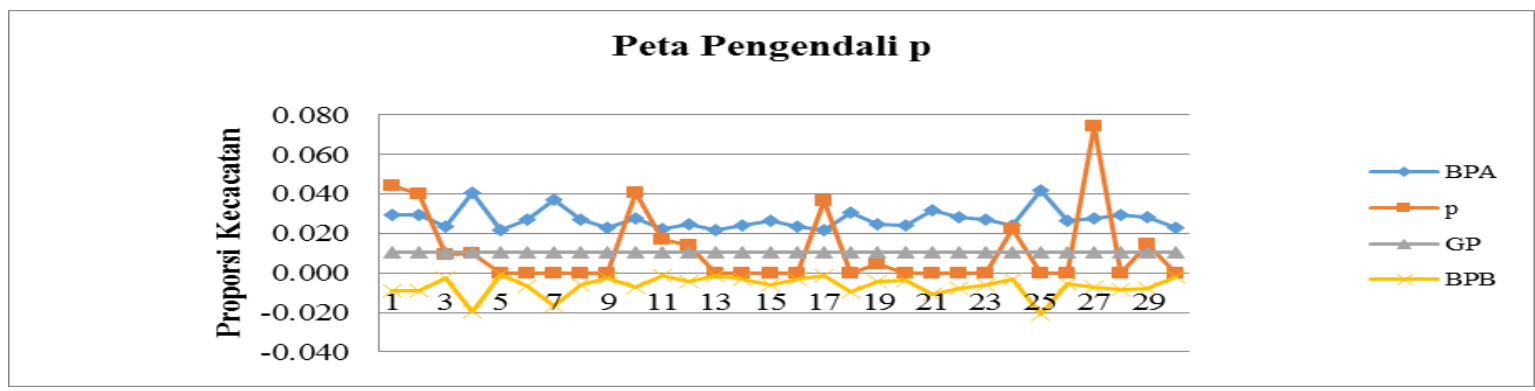

Gambar 1 Peta pengendali $\mathrm{p}$

Gambar 1 peta pengendali p di atas terdapat 5 data yang out of control yaitu data observasi ke-1, data observasi ke-2, observasi ke-10, observasi ke-17, dan observasi ke-27.

Tabel 3.

Data Out of Control Analisa $p$-chart

\begin{tabular}{|c|c|c|c|c|c|}
\hline \multirow{2}{*}{ No } & \multirow{2}{*}{ Observasi } & \multirow{2}{*}{$\begin{array}{l}\text { Jumlah } \\
\text { Lembar/ } \\
\text { hari }\end{array}$} & \multicolumn{3}{|c|}{ Data Cacat } \\
\hline & & & Sobek & Lorek & Ketipisan \\
\hline 1 & 1 & 250 & 1 & 0 & 10 \\
\hline 2 & 2 & 250 & 0 & 0 & 10 \\
\hline 3 & 10 & 297 & 5 & 7 & 0 \\
\hline 4 & 17 & 681 & 25 & 0 & 0 \\
\hline 5 & 27 & 297 & 4 & 7 & 11 \\
\hline
\end{tabular}

3.5 Jenis cacat tertinggi. Kecacatan rangking tertinggi berdasarkan jenis kecacatan per-observasi adalah sebagai berikut:

Tabel 4.

Kecacatan Rangking Tertinggi Per-observasi

\begin{tabular}{|l|l|l|l|}
\hline No & Observasi & Cacat Tertinggi & $\begin{array}{l}\text { Jumlah } \\
\text { Cacat }\end{array}$ \\
\hline 1 & 1 & Ketipisan & 10 \\
\hline 2 & 2 & Ketipisan & 10 \\
\hline 3 & 10 & Lorek & 7 \\
\hline 4 & 17 & Sobek & 25 \\
\hline 5 & 27 & Ketipisan & 11 \\
\hline
\end{tabular}

Berdasarkan tabel di atas, dapat disimpulkan bahwa cacat tertinggi adalah kecacatan pada jenis sobek dengan nilai 
25, kemudian kecacatan pada jenis ketipisan dengan nilai 11 , dan terakhir kecacatan pada jenis lorek dengan nilai 7 .

Kecacatan rangking tertinggi berdasarkan total kecacatan data out of control. Dapat dilihat pada tabel 5 yang menerangkan bahwa kecacatan rangking tertinggi adalah kecacatan jenis sobek dengan total cacat sebesar 35, kemudian kecacatan jenis ketipisan dengan nilai sebesar 31, dan terakhir kecacatan jenis lorek dengan nilai sebesar 14 .

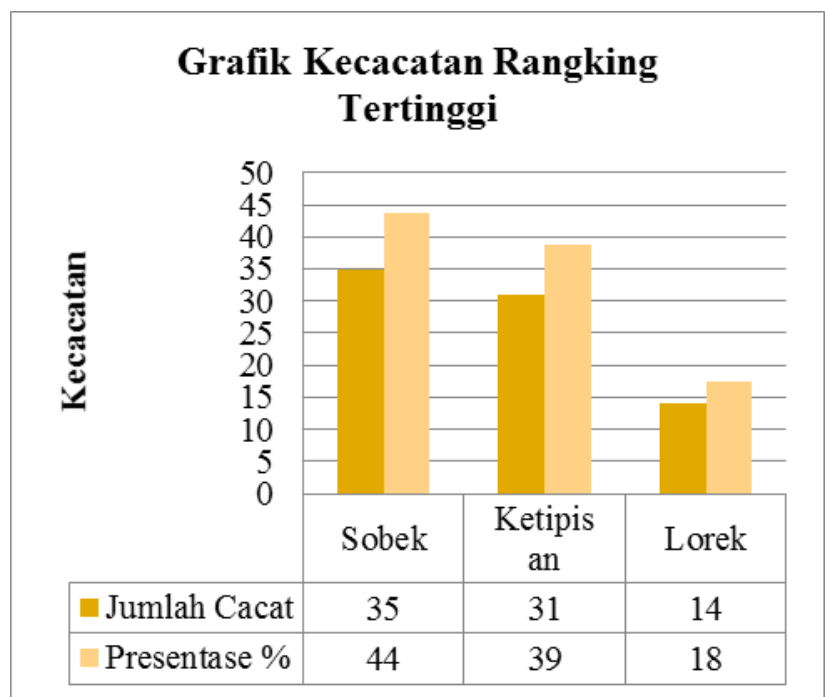

Gambar 4 Kecacatan rangking tertinggi berdasarkan total kecacatan

Pada perhitungan di atas, maka dapat diketahui urutan perbaikan yang lebih diprioritaskan adalah (a) kecacatan jenis sobek, (b) Kecacatan jenis ketipisan, (c) kecacatan jenis lorek.
Setelah diketahui urutan perbaikan yang lebih diprioritaskan, langkah selanjutnya yaitu menganalisis penyebab masalah atau kecacatan. Analisis bisa dilakukan dengan menggunakan diagram Ishikawa. Untuk mengetahui penyebab dari kecacatan produk, maka dilakukan wawancara langsung dengan karyawan yang bersangkutan salah satunya yaitu Bapak Nardi.

a. Kulit sobek

Faktor Manusia meliputi: pekerja yang mengantuk, pekerja kelelahan dalam bekerja, dan pekerja yang kurang berhati-hati dalam pengoperasian mesin maupun penempatan kulit pada mesin.

Faktor Lingkungan meliputi: penerangan yang kurang efektif seperti contoh ketika terjadi mendung sehingga mengakibatkan ruang kerja menjadi gelap dan pekerja menjadi terganggu dalam bekerja. Tempat yang cukup bising dalam hal ini juga dapat mengakibatkan pekerja kurang fokus dalam pekerjaannya.

Faktor Bahan Baku meliputi: tidak adanya seleksi bahan baku di awal yang berasal dari supplier, mutu bahan baku yang tidak sesuai dengan standar yang telah ditetapkan, kulit mentah yang benar-benar cacat dari awal, dan kulit yang terlalu kering.

Faktor Mesin meliputi: maintenance mesin yang masih kurang dioptimalkan, mesin mengalami error, rool pada mesin mengalami kemacetan, dan pisau shaving yang kurang tajam berdampak pada meningkatnya volume kecacatan jenis sobek sehingga memaksa perusahaan untuk menjual murah produk cacat tersebut.

Digambarkan dalam diagram Ishikawa sebagai berikut:

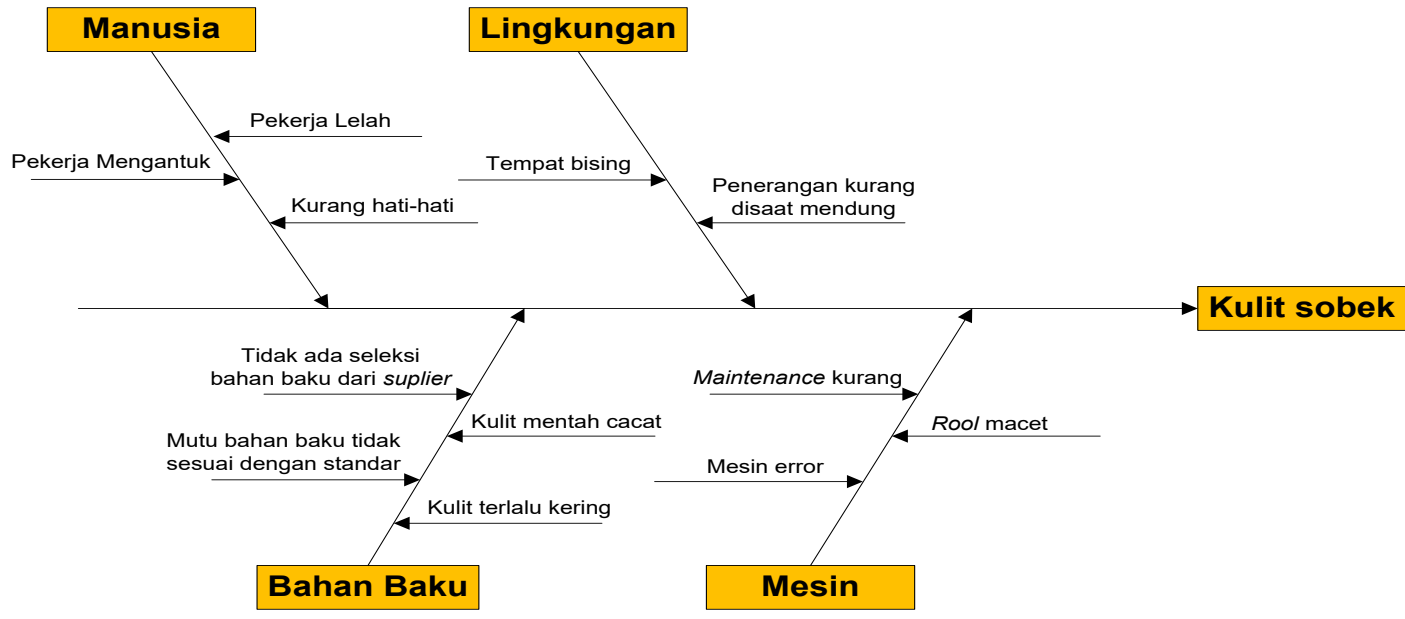

Gambar 2 Diagram Ishikawa kulit sobek

\section{b. Kulit ketipisan}

Faktor Manusia meliputi: kesalahan komunikasi atau instruksi manusia kepada mesin.

Faktor Bahan Baku meliputi: kulit mentah yang benarbenar dari awal sudah mengalami ketipisan.
Faktor Mesin meliputi: kesalahan dalam setting mesin seperti seharusnya kulit dibuat ketebalan $0.6 \mathrm{~mm}$ menjadi $<0.6$.

Digambarkan dalam diagram Ishikawa sebagai berikut: 


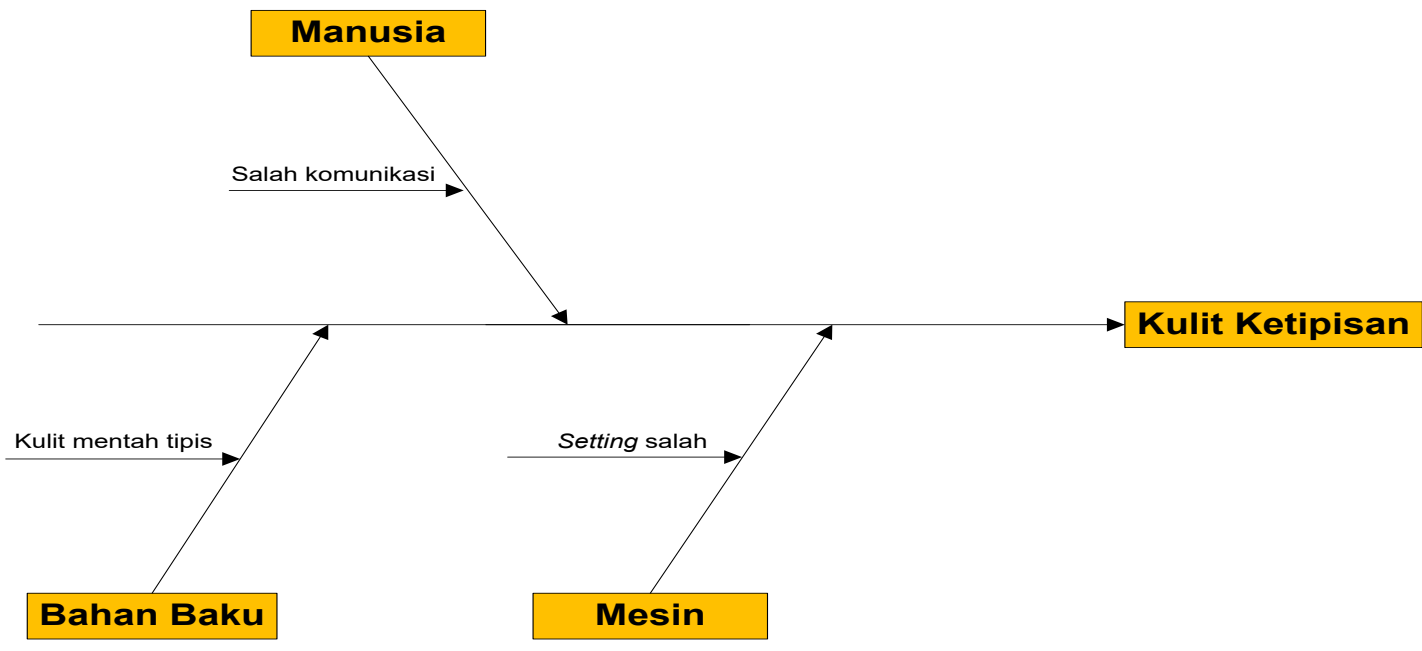

Gambar 3 Diagram Ishikawa kulit ketipisan

\section{c. Kulit lorek}

Faktor Manusia meliputi: pekerja yang mengantuk, pekerja kelelahan dalam bekerja, dan pekerja yang kurang dalam pengawasan dalam proses produksi.

Faktor Metode Kerja meliputi: cara pekerja dalam memasukkan kulit pada mesin yang terburu-buru sehingga mengakibatkan laju kulit yang terlalu cepat dan tidak terkontrol.

Faktor Bahan Baku meliputi: tidak adanya seleksi bahan baku di awal yang berasal dari supplier, mutu bahan baku yang tidak sesuai dengan standar yang telah ditetapkan, kulit mentah yang benar-benar cacat dari awal, kulit dari proses setting out yang masih mengkerut dan masih terlalu basah.

Faktor Mesin meliputi: maintenance mesin yang masih kurang dioptimalkan, mesin mengalami error, pisau shaving yang kurang tajam, dan perputaran mesin yang terlalu cepat.

Faktor Lingkungan meliputi: penerangan yang kurang efektif seperti contoh ketika terjadi mendung sehingga mengakibatkan ruang kerja menjadi gelap dan pekerja menjadi terganggu dalam bekerja.

Digambarkan dalam diagram Ishikawa sebagai berikut:

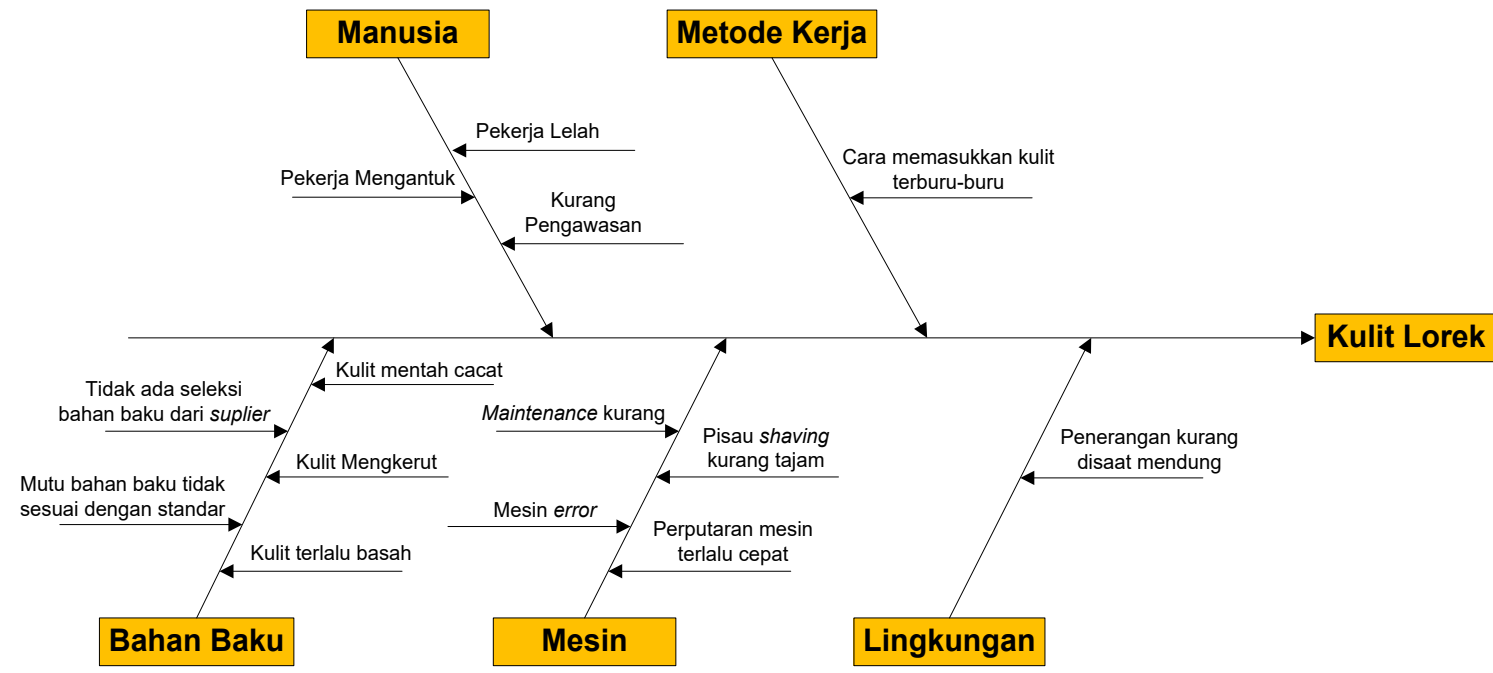

Gambar 4 Diagram Ishikawa kulit lorek

Penyebab kulit ketipisan disebutkan sebelumnya di atas salah satunya yaitu karena faktor bahan baku berupa kulit mentah. Maka dari itu, pada penelitian ini juga ingin mengetahui penyebab kulit mentah. Berikut adalah penyebab kulit mentah cacat:

\section{d. Penyebab kulit mentah cacat}

Faktor Hewan meliputi: fisik hewan yang sakit, umur yang sudah tua, berat badan yang minim.
Faktor Manusia meliputi: penyesetan kulit yang kurang terampil, proses penyesetan dilakukan terburu-buru, dan kurangnya pengawasan manusia terhadap hewan ternaknya semasa hidup atau juga kurangnya pengawasan manusia terhadap pekerjanya dalam penyesetan kulit.

Faktor Perawatan meliputi: kulit hewan yang terkena duri atau kawat, terkena benturan, kulit tercampuk, terpukul semasa hidup. 
Faktor Makanan meliputi: konsumsi makanan hewan yang kurang bergizi.

Faktor Lingkungan meliputi: hidup hewan yang dekat dengan pemangsa, adaptasi karena perpindahan tempat, kemudian faktor iklim (suhu, temperature, tekanan udara, kelembaban) yang tidak cocok terhadap hewan ternak. Untuk itu, salah satu upaya mendapatkan kualitas kulit domba yang baik, Gumilar, Putranto, dan Wulandari menjelaskan bahwa ketinggian tempat ternak domba di Kabupaten Garut berpengaruh pada kualitas kulit yang dihasilkan, kualitas kulit domba akan mempunyai kekuatan tarik dan tahan sobek dibandingkan dengan tempat ternak domba yang lebih rendah [18].

Untuk lebih memahami akibat dari kulit mentah yang cacat dapat dilihat pada diagram Ishikawa berikut ini:

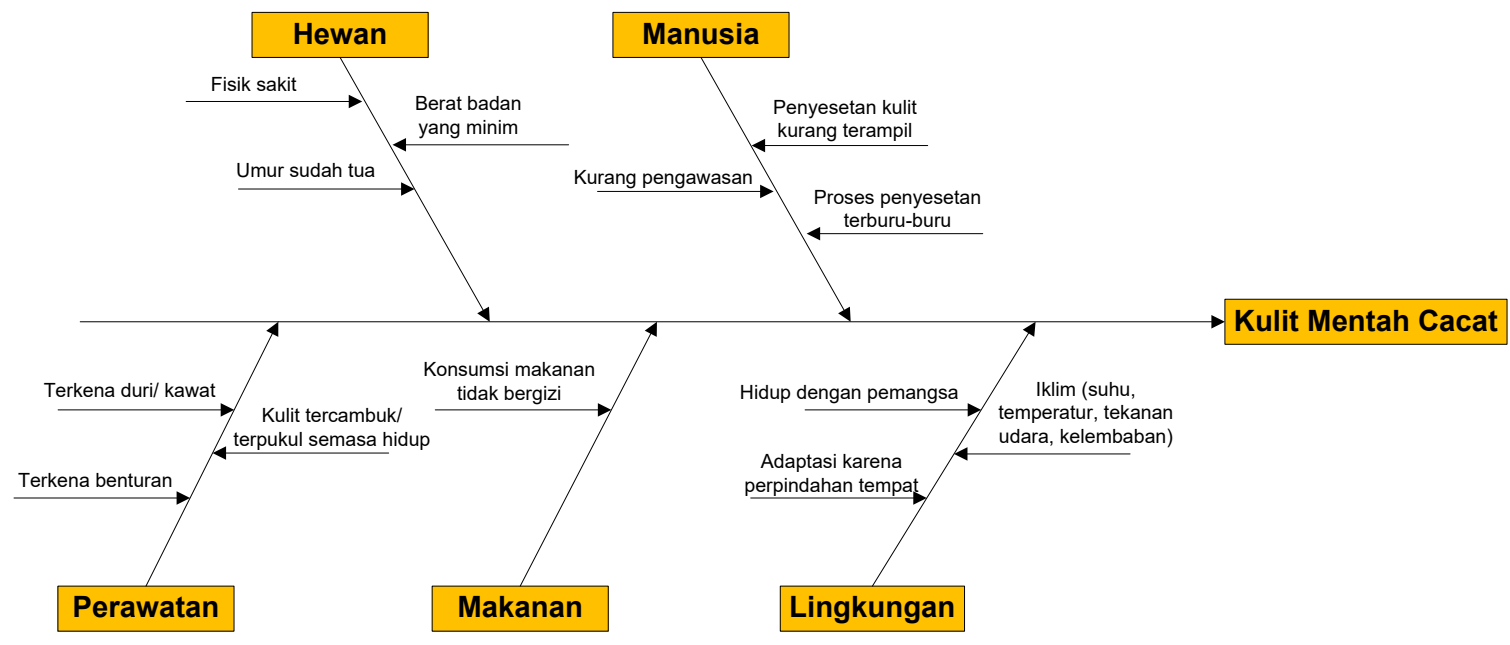

Gambar 5 Diagram Ishikawa kulit mentah cacat

\section{Kesimpulan}

Dari pengolahan yang telah dilakukan, maka dapat disimpulkan:

1. Pengamatan pada proses shaving (penyamakan kulit) didapat masih adanya produk yang tidak sesuai harapan (defect). Tiga macam produk defect adalah cacat jenis sobek, ketipisan, dan lorek.

2. Terdapat 5 data yang out of control yaitu jenis sobek sebanyak 35, jenis ketipisan sebanyak 31 , dan jenis lorek sebanyak 14. Sehingga prioritas yang menjadi perhatian dalam penanganannya yaitu pertama jenis sobek, kedua jenis ketipisan, dan yang ketiga jenis lorek.

\section{Referensi}

[1] Angelova, B., Measuring Customer Satisfaction with Service Quality Using American Customer Satisfaction Model (ACSI Model), International Journal of Academic Research in Business and Social Sciences, Volume 1, Number 3, 2011, pp. 232-258.

[2] Mujiraharjo, F.N., dan Basuki, M., Analisis Indeks Kepuasaan Masyarakat Terhadap Pelayanan Publik Bidang Kesehatan (Studi Kasus: Faskes Tingkat I Mojokerto), Jurnal Desiminasi Teknologi, Volume 7, Nomor 2, 2019, pp. 93-98.

[3] Fithri, P., dan Chairunnisa., Six Sigma Sebagai Alat Pengendalian Mutu Pada Hasil Produksi Kain Mentah PT Unitex Tbk, J@ti Undip: Jurnal Teknik Industri, Volume 14, Nomor 1, 2019, pp. 43-52.

[4] Windarti, T., Pengendalian Kualitas untuk Meminimasi Produk Cacat pada Proses Produksi Besi
Beton, J@ti Undip: Jurnal Teknik Industri, Volume 10, Nomor 3, 2014, pp. 173-180.

[5] Dharmawan, I.D., dan Ekawati, Y., Peningkatan Kualitas Knalpot Pada PT Fajar Indah, Jurnal Teknik Industri, Volume 15, Nomor 2, 2014, pp. 112-123.

[6] Devani, V., dan Wahyuni, F., Pengendalian Kualitas Kertas dengan Menggunakan Statistical Process Control di Paper Machine 3, Jurnal Ilmiah Teknik Industri (JITI), Volume 15, Nomor 2, 2016, pp. 87-93. [7] Idris, I., Sari, R.A., Wulandari., dan Uthumporn, U., Pengendalian Kualitas Tempe Dengan Metode Seven Tools, Jurnal Teknovasi, Volume 3, Nomor 1, 2016, pp. 66-80.

[8] Rimantho, D., dan Mariani, D. M., Penerapan Metode Six Sigma pada Pengendalian Kualitas Air Baku pada Produksi Makanan, Jurnal Ilmiah Teknik Industri (JITI), Volume 16, Nomor 1, 2017, pp. 1-12.

[9] Adyatama, A., dan Handayani, N.U., Perbaikan Kualitas Menggunakan Prinsip Kaizen dan 5 Why Analysis : Studi Kasus pada Painting Shop Karawang Plant 1, PT Toyota Motor Manufacturing Indonesia, J@ti Undip: Jurnal Teknik Industri, Volume 13, Nomor 3, 2018, pp. 169-176.

[10] Djunaidi, M., dan Ryantaffy, A.K., Analisis Nonconforming Part pada Wing Structure Pesawat Cn-235 dengan Menggunakan Metode FMEA (Failure Mode Effect Analysis), J@ti Undip: Jurnal Teknik Industri, Volume 13, Nomor 2, 2018, pp. 67-74.

[11] Hassan, E.A., Ibrahim, M.T., dan Sally, K.A., Optimisation of Chrome Retanning Process to the Garad (Acacis nilotica) Tanned Leather. Journal of Agricultural and Vaterinary Sciences (JAVS), Volume 
15, Nomor 1, 2014, pp. 87-94.

[12] Nasr, A.I., Abdelsalam, M., dan Azzam, A.H., Effect of Tanning Method and Region on Physical and Chemical Properties of Barki Sheep Leather, Egyptian Journal of Sheep and Goat Sciences, Volume 8, Nomor 1, 2013, pp. 123-130.

[13] Badan Pusat Statistik., Statistik Indonesia 2018. Jakarta, 2018.

[14] Basuki, M., Penentuan Rute Optimum Distribusi Produk PT Indmira Berdasarkan Jarak, Jurnal Desiminasi Teknologi, Volume 5, Nomor 1, 2017, pp. 1-7.

[15] Puspitasari, N.B., Arianie, G.P., dan Wicaksono, P.A., Analisis Identifikasi Masalah dengan Menggunakan Metode Failure Mode and Effect Analysis (FMEA) dan Risk Priority Number (RPN) pada Sub Assembly Line (Studi Kasus: PT. Toyota Motor Manufacturing
Indonesia), J@ti Undip: Jurnal Teknik Industri, Volume12, Nomor 2, 2017, pp. 77-84.

[16] Aribowo, B., dan Kushandayani., Analisis Pengendalian Kualitas Cacat Bintik untuk Produk Hyundai Atoz (Type Mx) Di PT Hyundai Indonesia Motor, J@ti Undip: Jurnal Teknik Industri, Volume 5, Nomor 3, 2010, pp. 217-224.

[17] Montgomery, D.C., Design and Analysis of Experiments, Eighth Edition, John Willey \& Sons, Inc, 2013.

[18] Gumilar, J., Putranto, W.S., dan Wulandari, E., Kualitas Kulit Sarung Tangan Golf dari Kulit Domba Priangan yang Berasal dari Berbagai Ketinggian Tempat di Kabupaten Garut, Jurnal Ilmu Ternak, Volume10, Nomor 2, 2010, pp. 61-64. 